

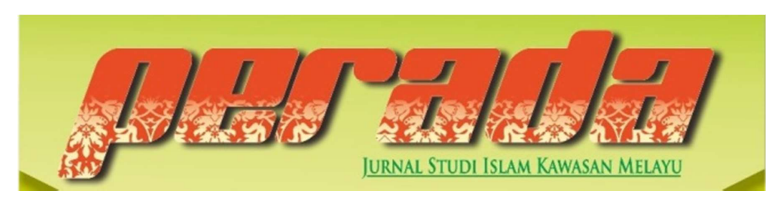

Perada: Jurnal Studi Islam Kawasan Melayu

ISSN 2656-7202 (P) ISSN 2655-6626 (0)

Volume 3 Nomor 1, Januari-Juni 2020

DOI: https://doi.org/10.35961/perada.v3i1.44

\title{
MANUSKRIP AL-QURAN PULAU PENYENGAT SEBAGAI KHAZANAH MUSHAF AL-QURAN DI KEPULAUAN RIAU
}

\author{
Dian Rahmawati \\ STAIN Sultan Abdurrahman Kepulauan Riau \\ rahmawati.dianiat@gmail.com
}

\begin{abstract}
Abstrak
Usaha penyalinan mushaf al-Quran di Indonesia salah satunya dilakukan oleh ulama-ulama yang berada di tanah Melayu Kepulauan Riau. Ini dibuktikan dengan ditemukannya manuskripmanuskrip al-Quran yang ditemukan di Pulau Penyengat dan di Pulau Lingga. Namun, sayangnya keberadaan manuskrip al-Quran di Pulau Penyengat saat ini mulai rusak termakan usia. Hal ini tentu akan menjadi kerugian besar sebagai aset sejarah yang berharga. Oleh karena itu kajian tentang manuskrip al-Quran di Kepulauan Riau, khususnya Pulau Penyengat dapat menjadi salah satu upaya pelestarian yang menjadi pilihan. Sehingga informasi mengenai keberadaan manuskripmanuskrip al-Quran di Pulau Penyengat tidak hanya menjadi cerita saja. Penelitian ini menggunakan penelitian kepustakaan (library research/literature review). Peneliti juga akan menggunakan observasi, wawancara dan dokumentasi. Adapun Manuskrip al-Quran yang terdapat di Pulau Penyengat yang berhasil diketahui berjumlah cukup banyak yakni 7(tujuh) manuskrip alQuran dan merupakan mushaf yang disusun sebagai hasil tulisan tangan. Kertas yang digunakan sebagai tempat menuliskan ayat-ayat suci al-Quran ini pada umumnya menggunakan kertas Eropa yang diperkirakan berasal dari abad Pertengahan. Gaya Sulawesi Selatan dapat ditemukan dalam gaya penulisan hurufnya, sedangkan Gaya Pantai Timur terlihat jelas dari gaya iluminasi floral yang terkesan mewah, indah, teliti dan bersepuh emas. Masing-masing manuskrip al-Quran Pulau Penyengat memiliki keunikan masing-masing. Namun, manuskrip-manuskrip ini sebagai khazanah mushaf al-Quran di Kepulauan Riau memiliki gaya dan ciri khas iluminasi yang disebut 'Gaya Sulawesi Selatan" dan Gaya Pantai Timur.
\end{abstract}

Kata Kunci : Manuskrip Al-Quran, Pulau Penyengat, Sejarah, Kondisi 
Abstract: One of the efforts to copy the manuscripts of the Koran in Indonesia was carried out by scholars in the Malay lands of the Riau Islands. This is evidenced by the discovery of Al-Quran manuscripts found on Penyengat Island and Lingga Island. However, unfortunately the existence of Al-Quran manuscripts on Penyengat Island is now starting to break down with age. This of course will be a big loss as a valuable historical asset. Therefore, the study of al-Quran manuscripts in the Riau Islands, in particular Penyengat Island, can be an option for preservation. So that information about the existence of al-Quran manuscripts on Penyengat Island is not just a story. This research uses library research / literature review. Researchers will also use observation, interviews and documentation. The manuscripts of the Koran found on Penyengat Island were found to be quite a lot, namely 7 (seven) al-Quran manuscripts and they were manuscripts compiled as handwritten. The paper used as a place to write the holy verses of the Koran generally uses European paper which is thought to have originated from the Middle Ages. The South Sulawesi style can be found in the writing style of the letters, while the East Coast Style is evident from the floral illumination style which is luxurious, exquisite, meticulous and gilded. Each of the Penyengat Island manuscripts of the Koran is unique. However, these manuscripts as the treasures of the Al-Quran manuscripts in the Riau Islands have a style and characteristic of illumination called 'South Sulawesi Style' and East Coast Style

Kata Kunci: Keywords: Al-Quran Manuscript, Penyengat Island, History, Conditions

\section{PENDAHULUAN}

Usaha Jam'ul Quran (pengumpulan alQuran) atau yang dikenal dengan istilah Kodifikasi al-Quran pada dasarnya seiring dengan pengajaran al-Quran oleh Nabi kepada sahabat. Sebagaimana pengertian yang diberikan oleh Syekh Manna Khalil alQatan dalam bukunya Mabahits fi Ulum alQuran bahwa Jam'ul Quran yakni Hifzubu dan Kitabatubu. ${ }^{1}$ Suyuti juga menyebutkan penulisan al-Qur'an sejatinya sudah dilakukan sejak masa awal Islam. ${ }^{2}$ Seiring dengan penyebaran agama Islam yang semakin meluas, kegiatan penyalinan mushaf al-Quran juga dilakukan oleh para ulama yang tersebar di berbagai daerah di Indonesia. Hal ini sehubungan dengan mulai berkembangnya pengajaran tulis baca alQuran. Pengajaran tulis baca al-Quran dilakukan di sekolah tradisional maupun keluarga. ${ }^{3}$ Penyalinan al-Quran menjadi

${ }^{1}$ Manna Khalil al-Qattan, Mabahits Fi Ulum Al-Quran (tt: Mansyurat al-'Asr al-Hadis, 1973), 118.

${ }^{2}$ Suyuti Jalaluddin, Al-Itqan Fi Ulum al-Qur'an (Beirut: Dar al-Fikr, 1999), 87.

${ }^{3}$ Tim Penyusun, Mushaf Al-Quran Di Rantau Melayu-Nusantara: Kahazanah Mushaf Al-Quran Di sebuah keniscayaan seiring dengan perkembangan tradisi pengajaran al-Quran yang semakin luas. Inilah yang menjadi salah satu faktor pendorong kegiatan penyalinan al-Quran di di Indonesia. Penyalinan mushaf al-Qur'an di Nusantara berlangsung dalam rentang waktu yang cukup Panjang sekitar 6500 tahun. Ada perkiraan telah ada sejak akhir abad ke-13, Mushaf yang tertua saat ini berada di Belanda yang menjadi koleksi William Marsden. Mushaf tersebut berasal dari Johor, Malaysia tahun $1606 .{ }^{4}$ Dalam usaha penyalinan tersebut dipengaruhi oleh berbagai latar belakang kebudayaan yang beragam, corak mushaf yang dihasilkan pun akhirnya memiliki ciri khas masing-masing baik dalam kaligrafi maupun iluminasi. Untuk mushaf di Indonesia sendiri yang saat ini dipergunakan adalah Mushaf yang telah

\footnotetext{
Kepulauan Riau (Jakarta: Lajnah Pentashihan Mushaf al-Quran, 2014), 21.

${ }^{4}$ Ali Akbar, Mushaf Al-Qur'an Di Indonesia Dari Masa Ke Masa (Badan Litbang dan Diklat Kementrian Agama RI, 2011), 10.
} 
sesuai dengan Mushaf Al-Quran Standar Indonesia. $^{5}$

\section{SEJARAH KEBERADAAN MANUS- KRIP AL-QURAN PULAU PENYENGAT KEPULAUAN RIAU}

Informasi tentang sejarah keberadaan manuskrip Al-Quran di Pulau Penyengat ini Berdasarkan pesan yang tertulis pada mushaf yang terdapat di Pulau Penyengat ini, dikatakan bahwasanya mushaf tersebut selesai disalin pada tahun 1867 oleh seorang penduduk Penyengat bernama Abdulrahman, seorang yang disebut sebagai seorang yang dikenal mahir dalam menulis khat yang indah.

Beliau pernah dikirim oleh Kerajaan Riau-Lingga ke Mesir untuk memperdalam ilmu agama. Sekembalinya dari Mesir beliau kembali ke Penyengat dan menjadi guru dan semakin terkenal dengan seni khatnya yang indah. Khatnya kemudian dikenal "Khat Istambul" dan karena itu pula nama Istambul melekat di belakang namanya, yakni Abdurrahman Stambul. Kepiawaian Abdurrahman dalam seni khat dan kedalaman penguasaan agamanya membuat mushaf yang beliau tulis istimewa. ${ }^{6}$

\section{BENTUK MANUSKRIP AL-QURAN KEPULAUAN RIAU PULAU PENYENGAT}

\section{MUSHAF I}

Mushaf ini merupakan manuskrip yang bersejarah, dan sangat penting, koleksi

5 Tim Penyusun, Sejarah Penulisan Mushaf AlQuran Standar Indonesia (Jakarta: Lajnah Pentashihan Mushaf al-Quran, 2013), 90.

6 Penyusun, Mushaf Al-Quran Di Rantau Melayu-Nusantara: Kahazanah Mushaf Al-Quran Di Kepulauan Riau, 22; Aswandi Syahri, "Mushaf AlQuran Kerajaan Riau-Lingga," Tanjungpinang Pos (Tanjungpinang, June 3, 2018), Minggu edition.
Masjid Raya Sultan Riau, Pulau Penyengat. Naskah ini ditulis di Kedah (Malaysia sebelah utara), selesai pada 25 Ramadan 1166 H (26 Juli 1753). Penyalinnya adalah Ali bin Abdullah bin Abdurrahman, seorang keturunan Bugis dari Wajo, yang menyelesaikan mushaf tersebut pada masa Sultan Muhammad Jiwa, seorang sultan yang alim dan warak, memerintah negeri Kedah pada 1710-1778. Mushaf ini diduga dibawa ke Pulau Penyengat oleh Raja Haji Fisabilillah (1727-1784) sekembalinya dari penyerbuan ke negeri Kedah pada 1770.

Kondisi mushaf ini dari tahun ke tahun semakin rusak, dan saat ini hampirhampir tidak bisa dibuka lagi, karena kertas mushaf 'termakan' tinta yang mengandung semacam zat besi (iron gall). Halaman kolofon, misalnya, yang pada tahun 2007 masih terbaca, meskipun kertas sudah pecah-pecah, tahun 2011 lalu sebagian besar sudah rontok dan tidak bisa terbaca lengkap lagi.

Mushaf ini merupakan satu keluarga dengan empat mushaf lain, yaitu (1) koleksi Perpustakaan Nasional RI Jakarta nomor A.49, dengan tarikh Sya'ban 1143 H (Februari/Maret 1731); (2) Mushaf Sultan Ternate, bertarikh 9 Zulhijah 1185 (14 Maret 1772); (3) satu buah mushaf lain di Museum Babullah istana Ternate, tanpa kolofon; dan (4) sebuah mushaf koleksi The Aga Khan Trust di Jenewa, Swiss, bertarikh 25 Ramadan 1219 H (28 Desember 1804). Kelima mushaf ini memiliki kesamaan dalam berbagai hal, terutama gaya tulisan dan iluminasinya, di samping kesamaan dalam teks-teks tambahan berupa catatan qiraat yang lengkap, salinan ulumul-Qur'an di awal dan akhir mushaf, serta perhitungan jumlah huruf dalam Al-Qur'an. Iluminasi mushafmushaf tersebut mempunyai akar yang sama, yaitu apa yang disebut sebagai "gaya Sulawesi Selatan”. 
Kolofon di halaman akhir mushaf selengkapnya berbunyi:

"Wa keana al-farägh min tabsili hāzà almushaf al-karim nahāra al-Jum'at min Ramadhān fi waqti al-'asri madat khamsa wa isyrüna yauman min syahri Ramadhān al-mubārak fi Bandar Kedah qaryah Padang Saujana fi zamāni Maulānà Paduka Sri as-Sultān al-A'ram wa alKhäqan wa al-A'dal al-Afkham Mubammad Jiwa Zain al-'Ádilin Mu'azzam Syah sanat 1166 alf wa mi'at wa sitt wa sittūn min al-bijrat annabawiyyah 'alà sābibihà afdal as-salāti wa aఇka at-taslim bi-khatt al-faqir al-khaqir ad-da'if almu'tarif bi az-zanbi wa at-taqsì ar-räji ilā 'afwi rabbibi al-karim Ali bin Abdulläh bin Abdurrabmān al-jāwi al-Būqisì al-W äjūwi asySyäfi' maz̧haban at-Tempe baladan wa maulidan wa watanan wa an-Naqsyabandi ... ... Maulānā as-Sultān 'Aläuddìn bin al-marbūm ... ghafara Allähu lahum wa li-wālidaibim wa li-jamìilmuslimin wal-muslimät wal-mu'minin [wa almu'minin] wal-mu'minät al-abyä'i minbum walamwāt."

Artinya: Selesai menyalin mushaf yang mulia ini siang Jumat, Ramadhan pada waktu asar, 25 bulan Ramadhan yang penub berkah di Kota Kedah desa Padang Saujana [Sejana] pada zaman Maulana Paduka Sri Sultan Yang Agung, Pemimpin Yang Adil Yang Besar Mubammad Jiwa Zain al-'Adilin Mu'azzam Syah tahun 1166 seribu seratus enam pulub enam Hijrab Nabi pemilik salawat yang utama dan salam yang suci, dengan tulisan yang fakir yang hina yang lemah yang mengakui dosanya dan kekurangannya yang mengharapkan ampunan Tubannya Yang Mulia, Ali bin Abdullah bin Abdurrabman al-jawi alBuqisi al-Wajumi, Syafi'i mazhabnya, Tempe daerabnya dan kelabirannya serta negerinya, Naqsyabandi ... ... Maulana Sultan 'Ala'uddin bin al-marbum ... semoga Allah mengampuni mereka dan orang tua mereka serta semua kaum muslimin dan muslimat, mukminin dan mu'minat yang masib hidup dan yang telah wafat.

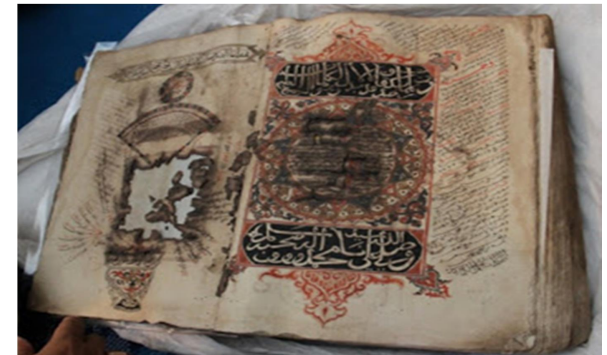

\section{MUSHAF II}

Mushaf indah ini berukuran $40 \times 25$ $\mathrm{cm}$, tebal $7 \mathrm{~cm}$. Kertas Eropa, dengan cap kertas semacam perisai dan cap tandingan berupa huruf IV atau VI. Kondisi mushaf masih cukup baik, lengkap 30 juz. Setiap halaman terdiri atas 15 baris, dengan model "ayat pojok". Mushaf ini mengalami penjilidan ulang di Singapura pada tahun 1956. Kemungkinan, pada saat penjilidan ulang ini, pinggiran mushaf dipotong, sehingga sebagian iluminasi yang indah di bagian dalam mushaf terpotong. Iluminasi mushaf bermotif floral yang mewah, bersepuh emas, terdapat di awal dan tengah mushaf. Di samping itu terdapat tiga 'iluminasi kepala' di bagian atas halaman, yaitu di awal juz ke-4, awal juz ke-30, dan akhir mushaf. Gaya iluminasi mushaf ini dapat digolongkan ke dalam gaya "Pantai Timur" Semenanjung Melayu, yang memang terkenal mewah, indah, teliti, dan sering bersepuh emas.

Menurut catatan di kotak mushaf, Al-Qur'an ini selesai disalin pada tahun 1867 oleh Abdurrahman Stambul, seorang penduduk Pulau Penyengat yang dikirm oleh Kerajaan Lingga ke Mesir untuk memperdalam ilmu agama dan khat. Mushaf ini berada di dalam Masjid Raya Sultan Riau, Pulau Penyengat, ditempatkan di dalam kaca khusus, di atas rehal lama yang diukir cantik. 


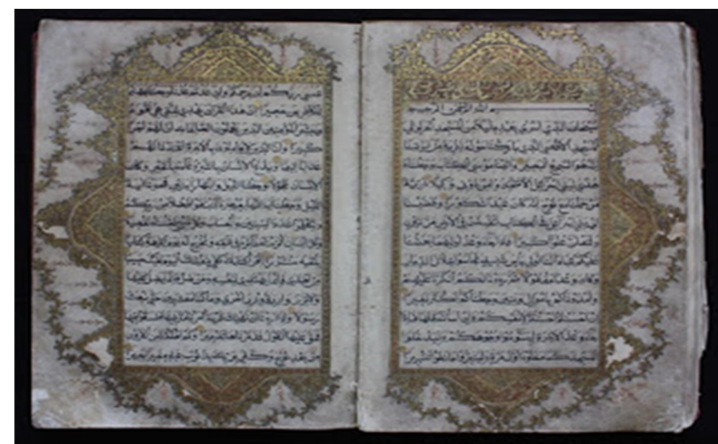

Iluminasi tengah mushaf, awal Surah al-Isra'.

\section{MUSHAF III}

Mushaf ini disimpan di dalam lemari kitab di Masjid Raya Sultan Riau, Pulau Penyengat, berkode 123. Saat ini kondisi mushaf sangat rapuh, rusak 'dimakan' tinta di hampir semua halaman. Bagian depan dan belakang mushaf telah hancur. Kertas Eropa yang digunakan mushaf ini rusak, kehitaman, khususnya di bagian teks ayat. Model teks yang digunakan adalah 'ayat pojok', setiap halaman terdiri atas 15 baris tulisan. Iluminasi terdapat di setiap awal juz, berupa hiasan bersepuh emas di bagian atas halaman. Melihat motif hiasannya, iluminasi mushaf ini dapat dimasukkan ke dalam gaya "Pantai Timur" Semenanjung Melayu.

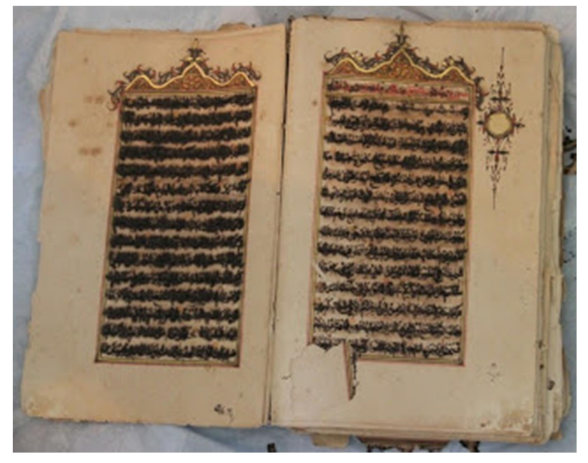

Koleksi Masjid Raya Sultan Riau, Pulau Penyengat

\section{MUSHAF IV}

Mushaf ini berkode 124, disimpan di dalam lemari kitab di Masjid Raya Sultan Riau, Pulau Penyengat. Kondisi mushaf telah rusak, kehitaman, khususnya di bagian bawah, diduga karena terkena air. Mushaf dengan kertas Eropa ini tipis, terdiri atas beberapa jilid. Baris-baris teks ayat ditulis jarang, dan antarbaris digunakan untuk terjemahan dalam bahasa Melayu dengan pola tulisan menggantung. Mushaf ini merupakan salah satu jilid dari satu set mushaf Al-Qur'an terjemahan. Salah satu jilid lainnya, yang semula tergabung dalam satu set yang sama, disimpan di Pusat Maklumat Kebudayaan Melayu, tidak jauh dari Masjid Sultan. Melihat gaya iluminasi yang terdapat di awal Surah as-Safat/37, juga huruf 'ain untuk tanda rukuk, juga model penulisan setiap kepala surah, memperlihatkan dengan jelas bahwa mushaf ini dapat digolongkan ke dalam "gaya Sulawesi Selatan".

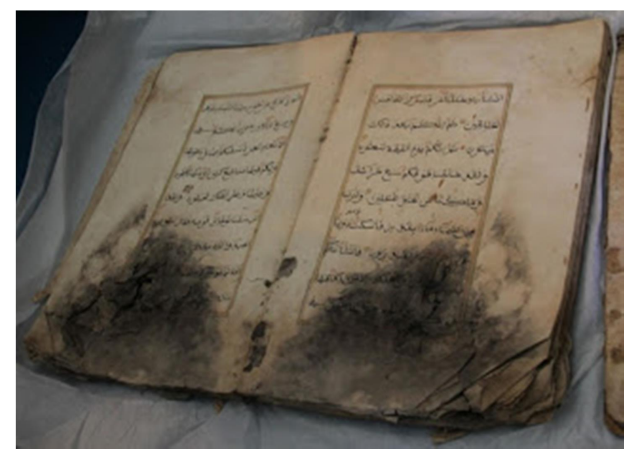

Koleksi Masjid Raya Sultan Riau, Pulau Penyengat

\section{MUSHAF V}

Manuskrip ini merupakan koleksi Pusat Maklumat Kebudayaan Melayu, yang terletak sekitar 200 meter dari Masjid Raya Sultan Riau di Pulau Penyengat. Naskah ini merupakan salah satu dari sebuah set terjemahan Al-Qur'an dalam bahasa Melayu 
yang terdiri atas beberapa jilid. Terjemahan ditulis dengan model menggantung di selasela baris ayat. Kondisi naskah dengan kertas Eropa ini agak rusak, terutama di bagian bawah, karena lembab.

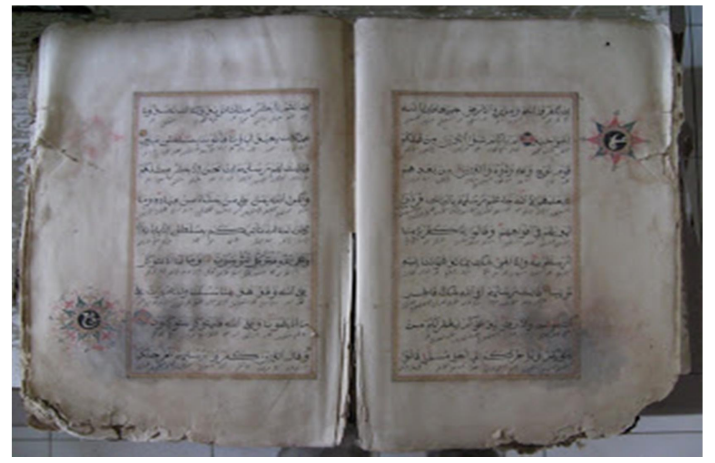

Koleksi Pusat Maklumat Kebudayaan Melayu, Pulau Penyengat

\section{MUSHAF VI}

Manuskrip ini merupakan salah satu dari dua koleksi mushaf yang terdapat di Pusat Maklumat Kebudayaan Melayu, Pulau Penyengat. Mushaf ini merupakan "AlQur'an ayat pojok", setiap halaman terdiri atas 15 baris tulisan. Kertas Eropa, diperkirakan dari pertengahan abad ke-19. Kondisi mushaf cukup baik, meskipun bagian awal dan akhir mushaf tidak lengkap lagi. Sebagaimana umumnya mushaf dalam "gaya Pantai Timur", setiap awal juz dimulai dari halaman di sebelah kanan, dan ditandai dengan medalion bertuliskan "al-juг".

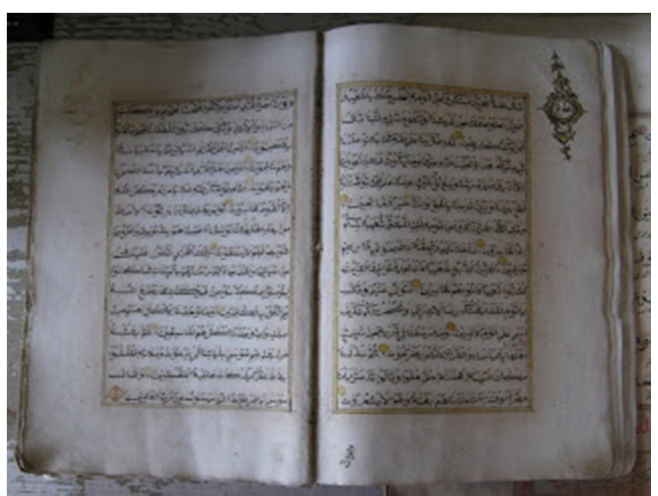

Koleksi Pusat Maklumat Kebudayaan Melayu, Pulau Penyengat.

\section{MUSHAF VII}

Di samping mushaf-mushaf manuskrip di atas, terdapat pula mushaf cetak dalam jumlah cukup banyak, khususnya yang disimpan di lemari Masjid Raya Sultan Riau, Pulau Penyengat. Di antaranya adalah mushaf cetakan Bombay, India, akhir abad ke-19 atau awal abad ke20. Mushaf cetakan seperti itu dahulu beredar cukup luas di Nusantara, dari Palembang, Demak, madura, Lombok, Bima, hingga Filipina Selatan.

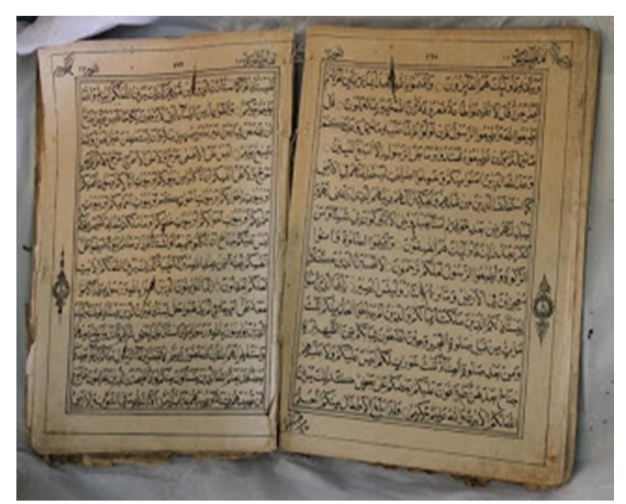

Mushaf cetakan India, akbir abad ke-19, atan awal abad ke-20. 


\section{CIRI KHAS DAN KONDISI MANUS- KRIP AL-QURAN PULAU PENYE- NGAT}

\section{Ciri Khas Manuskrip Al-Quran Pulau Penyengat}

Dengan mengetahui berbagai ragam manuskrip al-Quran Pulau Penyengat, maka dapat dilihat beberapa ciri khas penulisan atau ragam iluminasi di dalamnya, seperti berikut:

a. Manuskrip Al-Quran Pulau Penyengat yang tersimpan di Mesjid Raya Sultan Riau Penyengat merupakan hasil tulisan tangan

b. Kertas yang digunakan sebagai tempat menuliskan ayat-ayat suci alQuran ini pada umumnya menggunakan kertas Eropa yang diperkirakan berasal dari abad Pertengahan.

c. Gaya iluminasi yang paling sering digunakan di dalam ke tujuh manuskripnya adalah "Gaya Sulawesi Selatan” dan Gaya Pantai Timur".

Gaya Sulawesi Selatan dapat ditemukan dalam gaya penulisan hurufnya, sedangkan Gaya Pantai Timur terlihat jelas dari gaya iluminasi floral yang terkesan mewah,indah, teliti dan bersepuh emas.

\section{Kondisi Manuskrip Al-Quran Pulau Penyengat}

Berdasarkan hasil penelitian yang telah dilakukan, kondisi manuskrip alQuran di Pulau Penyengat ini cukup memprihatinkan. Selain dari satu buah manuskrip yang masih dipajang dan dilapisi oleh kotak kaca di dalam Mesjid Raya Sutan Riau Penyengat. Kondisi manuskrip lainnya kurang mendapatkan perawatan.

temukan: a. Mushaf yang bisa dilihat oleh masyarakat luas hanya satu yang dipajang didalam kotak kaca yang berada di dalam masjid Penyengat

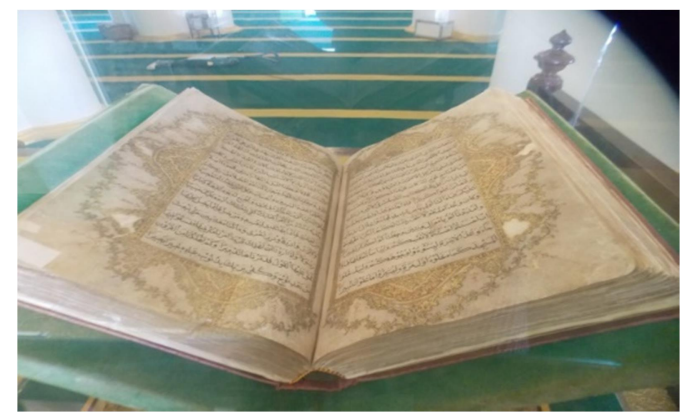

Gambar Mushafyang dipajang di Mesjid Sultan Riau pulau Penyengat

b. Berbagai manuskrip yang dimiliki oleh Mesjid Penyengat hanya tersimpan di dalam lemari kayu

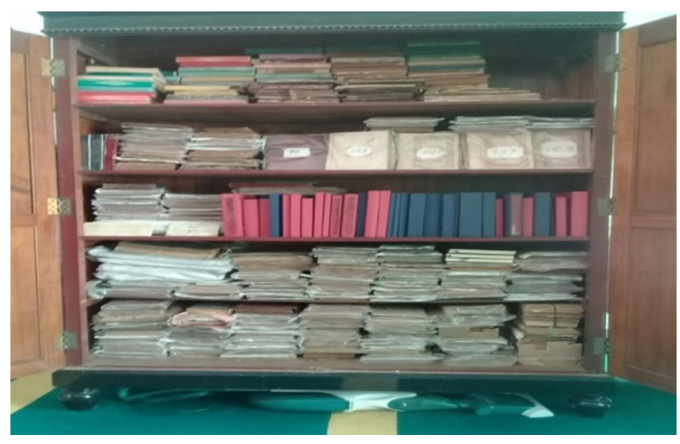

Gambar simpanan naskah yang berada di Pulau Penyengat

c. Kondisi yang cukup memprihatinkan

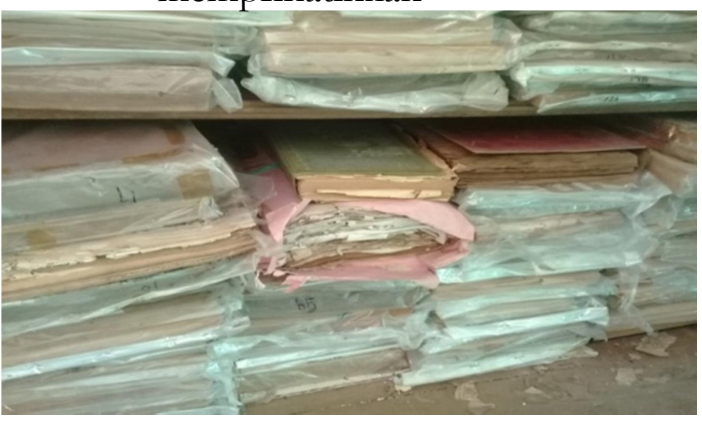

Gambar kondisi Naskah Penyengat 
d. Masih belum dilakukan upaya restorasi untuk menjaga kertas manuskrip dari pelapukan dan hangus akibat tinta khat yang digunakan.

Manuskrip al-Quran Pulau Penyengat sebagai khazanah al-Quran Kepulauan Riau merupakan hal yang sangat berharga yang telah dimiliki dan seharusnya dapat dijaga dan diperhatihatikan sebagai mestinya. Kurangnya perawatan dan perhatian terhadap manuskrip yang ada dikhawatirkan akan menjadikan manuskrip al-Quran ini hanya menjadi sebuah cerita bagi generasi selanjutnya

\section{KESIMPULAN}

Gambaran sebagaimana yang telah dipaparkan di atas, maka dapat disimpulkan beberapa hal sebagai berikut. Pertama, berdasarkan dari bukti fisik yang ada dan bisa dipertanggungjawabkan yaitu informasi dari pesan yang tertulis pada salah satu mushaf yang terdapat di Pulau Penyengat. Penulis mendapatkan bahwasanya mushaf tersebut selesai disalin pada tahun 1867 oleh seorang penduduk Penyengat bernama Abdurrahman yang dikenal mahir dalam menulis khat yang indah. Beliau pernah dikirim oleh Kerajaan Riau-Lingga ke Mesir untuk memperdalam ilmu agama. Sekembalinya dari Mesir beliau kembali ke Penyengat dan menjadi guru dan semakin terkenal dengan seni khatnya yang indah. Khatnya kemudian dikenal "Khat Istambul" Kepiawaian Abdurrahman dalam seni khat dan kedalaman penguasaan agamanya membuat mushaf yang beliau tulis istimewa. Kedua, manuskrip al-Quran yang terdapat di Pulau Penyengat yang berhasil diketahui berjumlah cukup banyak yakni tujuh manuskrip al-Quran dan merupakan mushaf yang disusun sebagai hasil tulisan tangan. Kertas yang digunakan sebagai tempat menuliskan ayat-ayat suci al-Quran ini pada umumnya menggunakan kertas Eropa yang diperkirakan berasal dari abad Pertengahan. Gaya Sulawesi Selatan dapat ditemukan dalam gaya penulisan hurufnya, sedangkan Gaya Pantai Timur terlihat jelas dari gaya iluminasi floral yang terkesan mewah, indah, teliti dan bersepuh emas. Masing-masing manuskrip al-Quran Pulau Penyengat memiliki keunikannya masingmasing. Namun, manuskrip-manuskrip ini sebagai khazanah mushaf al-Quran di Kepulauan Riau memiliki gaya dan ciri khas iluminasi yang disebut 'Gaya Sulawesi Selatan" dan Gaya Pantai Timur"

\section{DAFTAR RUJUKAN}

Akbar, Ali. Mushaf Al-Qur'an Di Indonesia Dari Masa Ke Masa. Badan Litbang dan Diklat Kementrian Agama RI, 2011.

Jalaluddin, Suyuti. Al-Itqan Fi Ulum alQur'an. Beirut: Dar al-Fikr, 1999.

Penyusun, Tim. Mushaf Al-Quran Di Rantau Melayu-Nusantara: Kahazanah Mushaf Al-Quran Di Kepulauan Riau. Jakarta: Lajnah Pentashihan Mushaf alQuran, 2014.

\section{- Sejarah Penulisan Mushaf Al-Quran Standar Indonesia. Jakarta: Lajnah Pentashihan Mushaf al-Quran, 2013.}

al-Qattan, Manna Khalil. Mabahits Fi Ulum Al-Quran. tt: Mansyurat al-Asr alHadis, 1973. 
Syahri, Aswandi. "Mushaf Al-Quran

Kerajaan Riau-Lingga," Tanjungpinang

Pos. Tanjungpinang, June 3, 2018, Minggu edition. 